\title{
THE PERCEPTION OF THE GENERATIONAL ASSESSMENT OF SELECTED SOCIAL BEHAVIOUR - A CONFIRMATORY FACTOR ANALYSIS*
}

\author{
Agnieszka Stanimir, Ph.D., Associate Professor \\ Wroclaw University of Economics \\ Faculty of Economics and Finance \\ Department of Econometrics and Operational Research \\ Komandorska 118/120, 53-345 Wroctaw, Poland \\ e-mail: agnieszka.stanimir@ue.wroc.pl \\ ORCID: 0000-0002-9206-9210
}

Received 11 November 2019, Accepted 5 September 2020

\begin{abstract}
Research background: The search for stable factors affecting latent variables that reflect the assessment of quality of life in three areas of an individual's functioning is the background of the study. In the analysis was assumed the existence of the relationships between QoL assessment and subjective factors related to socio-economic aspects.
\end{abstract}

Purpose: The aim of the study was to recognize assessments in given areas of transferring subjective satisfaction with a level of social factors and checking the stability of the assumed relationship between factors describing three areas of functioning: household, country of residence, EU. The next goal was to compare the results obtained in the study of natural relationships between factors with the given systems of these factors in the areas of an individual's functioning. Characteristics of behaviour were compared in three generations of Europeans. The application objective of the study was to indicate the usefulness of SEM in the research problem.

Research methodology: The Standard Eurobarometer, autumn 2018, provided data describing adults from the generations Y, X, and BB. Structural equation models were used.

Results: The effect of the used method is the determination of the factors that affect the assessments made by three European Generations in the areas of an individual's functioning: direct, close and further.

Novelty: The analysis showed the usefulness of structural equation models to achieve the goals of the study.

\footnotetext{
* The project was financed under the program of the Minister of Science and Higher Education under the name "Regional Initiative of Excellence" in 2019-2022 project number 015/RID/2018/19 the amount of funding PLN 10,721,040.00.
} 
Keywords: generations Y, X, BB, structural equation models (SEM), quality of life (QoL)

JEL classification: C3, I31, R2, R5

\section{Introduction}

The aim of the study was to construct a model that allows assessing the impact of manifest indicators describing the perception of the satisfaction of Europeans in the socio-economic sphere of life regarding three areas of an individual's functioning: direct (household), close (place and country of residence), further (the EU and Europe). In addition, the aim of the study was to find differences between three generations of adult Europeans in terms of their assessments, which were reflected in the assumed model. It was decided to indicate which variables affect a better and worse assessment of the highlighted areas. The indirect objective enabling the realization of the main aim was to indicate structural equations models as a tool for thoroughly analysing the problem. The assessments provided by Europeans were of a subjective nature.

In the study the differences between the assessment made by three generations: Baby Boomers (1946-1964), Generation X (1965-1979), and Generation Y (1980-2000) were looked for. In the literature it is possible to find many studies highlighting the differences between generations in different spheres of their existence: social and consumer behaviour (Haque, Maheshwari, 2015; Belleau, Summers, Xu, Pinel, 2007; Lyons, Duxbury, Higgins, 2007; Madudova, Fabuš, 2017; Lichy, 2012; Ngobo, Devallet-Ezanno, 2010), personal vs. professional (Bąkowska, 2013; Favero, Heath, 2012; Hansen, Leuty, 2012; Mencl, Lester, 2014; Parry, Urwin, 2011; Soulez, Guillot-Soulez, 2011; Treuren, Anderson, 2010; Twenge, Campbell, Hoffman, Lance, 2010; Twenge, King, 2005; Vui-Yee, Paggy, 2018), and the use of new technologies (Madudova, Fabuš, 2017). Often in the literature can be found suggestions about the lack of strict differences between the generations (Stanimir, 2020; Treuren, Anderson, 2010). It should be remembered that generations go through very similar phases of personality development or social relations, but they have different resources to manifest their views and encounter other recipients. Each of them has at its disposal a different set of tools - economic, financial, social, and technical - and represents a different level of knowledge, advancement and need of use. It should be pointed out that younger generations seen from the perspective of the older ones will always be different, because their ways of behaving and decision-making are influenced by the changing social, economic, political and technological conditions. 
The selected research area and the variables indicated for its description are closely linked to the quality of life in a subjective way. Defining the quality of life depends on the perspective sketched for the problem by the researcher (Panek, 2014). In this case, the quality of life should be understood as human well-being, which is measured here with non-monetary traits that characterize individuals, traits that shape individuals' life chances and cause their cultural and social diversity. For most individuals, subjective well-being is most important in direct references to personal benefits. This assessment is also done by comparing themselves, their abilities and family environment with the abilities of other individuals. The variables selected in the present study fit into the trend that is observed in studies on quality of life. Modern research takes into account not only subjective factors related to the individuals' but also aspects of sustainable development and the protection of the human environment and cultural heritage (Panek, 2014). It should also be noted, according to Słaby (1990), that the assessment of subjective quality of life is associated with the feeling of being someone. In turn, Sęk (1993) indicates that quality of life assessment is the result of perceiving many processes in many spheres of life and concerns life as a whole. Therefore, the choice of variables from the available factors in the Eurobarometer survey includes both factors related to the perception of the quality of life as well-being and factors including the assessment of guaranteeing the stability of the development and individuals' functioning in many areas.

As the presented study is a continuation of the study described in Stanimir (2020), therefore the presented study also assumed that the positive or negative assessment of the quality of life in the area of characteristics closest to an individuals is associated with the assessment of life and functioning in the environment in the area characterized by features not directly connected with an individuals. Therefore, how quality of life is evaluated implies the assessment of the possibility of functioning in society, and reaching out further, in the EU and in Europe. In the previous study, no fixed relationship structures were assumed but their natural linkage were sought. In the present study, sets of observable factors have been identified that are associated with three designated areas of the individuals' functioning.

The study assumed that the groups of these factors are interrelated and there are relationships of assessments made by individuals for solutions and situations relevant to them. These assessments translate into evaluations of the comparison of these solutions with the solutions proposed in the country or place of residence and in the EU. Thus, feedback between particular groups of factors should be expected. On this basis, the following research hypotheses were formed: 
H1: The perception of the individuals' quality of life is interpreted as the relations between perception of the quality of life in the household, country and place of residence, the EU and Europe.

H2: The imposition of a division of factors describing the assessment of socio-economic conditions characterising individuals into three aspects of their functioning: direct (household), close (own environment and country of residence), and further (Europe and the EU) leads to distinguishing factors which are relevant in each of these aspects.

H3: There are differences between distinguished generational groups regarding the hierarchy of factors distinguished in particular areas of individuals' functioning.

\section{Data and applied methods of analysis}

The study used data gathered during the Standard Eurobarometer (European Commission, 2019) survey conducted in November 2018 in all EU member states as well as in countries applying for EU accession. The survey is cyclical, carried out twice a year using a personal interview. The research was based on the answers of adult Europeans from the generations $\mathrm{Y}, \mathrm{X}$ and BB. The analyses used the following variables: general condition of the country (X1), evaluation of the country's economy (X2), evaluation of the EU economy (X3), personal situation at work (X4), financial condition of the household (X5), evaluation of the country's jobs market (X6), evaluation of public services (X7), satisfaction with one's life (X8), expectations from one's life (X9), quality of life was better before EU accession (X10), satisfaction with democracy in the country (X11), satisfaction with EU democracy (X12), attachment to the place of residence (X13), attachment to the country (X14), attachment to the EU (X15), attachment to Europe (X16), feelings about the statement my voice counts in the EU (X17) and my voice counts in the country (X18), convincing acquaintances to my opinion (X19). The measure of the variables was carried out using a five-step scale, where the highest score was the most positive opinion (except for question X10). It was assumed that the variables describe the three areas of respondents' functioning: household (X4, X5, X8, X9, X10, X13, X19) - HH, country of residence (X1, X2, X6, X7, X11, X14, X18) - C, the EU (X3, X12, X15, X16, X17) - EU.

In order to verify the hypotheses and realise the postulated research problem, the structural equation modelling was used. This method has been widely described in the literature. Structural equation models are described in detail by Byrne (2001), Konarski (2009), Long (1983) and also Sztemberg-Lewandowska (2008). This article does not present algorithms of conducting an analysis using the selected methods, but merely refers to the indicators and assumptions regarding 
the correctness of the conclusions made. Structural equation models with a confirmatory factor analysis were used in the study. For this reason, starting to use SEM for ordinal variables, the assumptions and algorithm of a factor analysis should be familiarized. The factor analysis has been widely described in Backaus, Erichson, Plinke and Weiber (2003), Greenacre (2010), Kim and Mueller (1978), Ptak-Chmielewska (2009), Sztemberg-Lewandowska (2008).

Structural equations modelling allows determining the dependences between latent variables, while the factors influencing them constitute a structure defined by the researcher. Since analysing the posed research problem required the use of variables measured on the ordinal scale, in the modelling of structural equations a confirmatory factor analysis was applied. Construction of a model allows building a measurement model describing the influence of each of the observed factors on the latent variable, and also a structural model examining the relations between the latent variables. A confirmatory factor analysis is used to estimate the measurement (external) model, while the internal model describes both the direct and indirect relations between the distinguished factors (Osińska, Pietrzak, Żurek, 2011). The choice of the estimation method SEM depends on fulfilling the condition of the multivariate normal distribution and the size of the sample. Usually, when the condition of the multivariate normal distribution is met, the method of the maximum likelihood estimation is used, whereas when that condition is not fulfilled for small samples (200-500 observations) the method of Asymptotically Distribution Free (ADF) is employed, and for large samples (over 2,500 observations) those of Generalized Least Squares and Weighted Least Squares (for continuous variables that estimator is the ADF estimator). Moreover, in selecting the method of estimation, the scale of measurement for the variables is also relevant (Osińska, Pietrzak, Żurek, 2011). The problem of sample size is related to the complexity of the model (Szymańska, 2016), the more manifest variables and relationships with latent factors, the sample size should increase. Sagan (2003) indicates that the sample size depends on the number of variable's categories and the number of variables. For the simplest models, the sample should have 400 observations (Byrne, 2001; Sagan, 2003). However, it is not clear, what the affirmative of complex and simple models mean. Table 1 contains requirements found in the literature regarding the sample size, normal distribution of variables and the type of measurement scale corresponding to the most frequently cited estimation methods in SEM.

Finally, the estimated model should be verified. The literature provides several indicators which can help with checking the correctness of the model's estimation. In Table 2 the chosen indices of model assessment are given. 
Table 1. Popular methods used in the SEM estimation process

\begin{tabular}{|l|c|c|c|}
\hline \multicolumn{1}{|c|}{ Estimation method } & $\begin{array}{c}\text { Assumption } \\
\text { of Normality }\end{array}$ & Sample size & $\begin{array}{c}\text { Measurement } \\
\text { scale }\end{array}$ \\
\hline ML (Maximum Likelihood) & + & $>100$ & Metric \\
\hline ULS (Unweighted Least Squares) & +- & $>100$ & Metric \\
\hline GLS (Generalized Least Squares) & + & $>100$ & Metric \\
\hline SLS (Scale Free Least Squares) & - & $>2500^{*}$ & Nonmetric \\
\hline & - & $1.5 \cdot p(p+1)$ & Metric \\
ADF (Asymptotically Distribution Free) & & $\begin{array}{c}\text { Min } 500 \\
5000^{*}\end{array}$ & Nonmetric \\
\hline WLS (Weighted Least Square) & $+/-$ & 500 & $5000^{*}$ \\
\hline
\end{tabular}

*For complex models; $p$ - number of observed variables; $\mathrm{df}$ - degrees of freedom.

Source: own study based on Backhaus, Erichson, Plinke and Weiber (2003), Biesok and Wyród-Wróbel (2016), Januszewski (2011), Konarski (2009), Long (1983), Sagan (2003, 2018), Sztemberg-Lewandowska (2008), Szymańska (2016).

Table 2. Goodness-of-fit indices

\begin{tabular}{|c|c|}
\hline Index & Reference level \\
\hline Cronbach's alpha & $>0.7$ \\
\hline CR (Jöreskog Rho) (construct reability) & $>0.7$ \\
\hline AVE (Average Variance Extracted) & 0.5 \\
\hline$C M I N=\chi^{2}$ & $\begin{array}{c}\text { the value should be the smallest possible and also statistically } \\
\text { insignificant, if } p>0.05 \text { then the imposed restrictions } \\
\text { are correct. Sample size sensitive }\end{array}$ \\
\hline$\chi^{2} / d f$ & $\begin{array}{c}\max 2 \\
\max 5 \\
\text { (should be close to } 1, \text { excepted ULS, SLS) }\end{array}$ \\
\hline $\begin{array}{l}\text { RMSEA } \\
\text { (Root Mean Square Error of Approximation) }\end{array}$ & $\begin{array}{c}\leq 0.05 \text { close model fit, } \\
(0.05,0.08) \text { satisfactory goodness-of-fit, } \\
\langle 0.08,0.1\rangle \text { a poor fit; reasonable model, } \\
>0.1 \text { unaccepted (model is disqualified) }\end{array}$ \\
\hline GFI (Goodness-of-Fit Index) & $\begin{array}{l}\geq 0.95 \\
\geq 0.9 \\
\geq 0.8\end{array}$ \\
\hline AGFI (Adjusted Goodness of Fit Index) & $\begin{array}{l}\geq 0.9 \\
\geq 0.8\end{array}$ \\
\hline NFI (Normed Fit Index) & $\geq 0.9$ \\
\hline CFI (Comparative Fit Index) & $\geq 0.9$ \\
\hline $\mathrm{AIC}, \mathrm{BIC}$ & the lower the values the better \\
\hline RMR (Root Mean Square Residual) & $\begin{array}{l}\text { the smaller the RMR is, the better; an RMR of zero } \\
\text { (saturated mode) indicates a perfect fit; the RMR, } \\
\text { farthest from the value of the independent model indicated } \\
\text { better adjustment }\end{array}$ \\
\hline
\end{tabular}

Source: own study based on Byrne (2001), Backhaus, Erichson, Plinke and Weiber (2003), Biesok and Wyród-Wróbel (2016), Januszewski (2011), Konarski (2009), Long (1983), Sagan (2018), Sztemberg-Lewandowska (2008), Szymańska (2016). 
Table 2 contains the most commonly used indicators of the assessment of the goodness of a model's fit. As indicated by Biesok and Wyród-Wróbel (2016), the assessment of the model should be performed by several indicators. Therefore, the assessment of the model should be made on the basis of selected indicators, e.g. presented in the table, because they include verification of the model in many aspects: absolute fit measure (GFI, AGFI, RMR), relative fit measure (NFI, CFI), measure of approximation divergence (RMSEA), measures based on information theory (AIC, BIC), reliability assessment (Cronbach's alpha), assessment of constructs in CFA (CR, AVE).

\section{Search for relations between the latent factors describing areas of individuals' functioning}

Another step in the carried out study was to ascertain whether the set structure of latent variables describing particular areas of the functioning of individuals are comparable for each of the generations. For this purpose, we carried out the modelling of structural equations with a confirmatory factor analysis. The latent factors were the areas of the functioning of individuals, i.e. a household - HH, country of residence - C, the European Union - EU.

Due to the observed skewness of distribution of the analysed variables we refrained from the estimation of models MNW. For this situation, the literature provides indications for the use of the method from the group asymptotically free from distribution methods. Because the ADV method is used for metric variables, Scale Free Least Squares (SLS) was used (the size of the sample in each group significantly exceeded five thousand).

Table 3 presents the components of the model and reliability coefficients. In the structural model we assumed that there is a relationship between all constructs (latent factors). In the measurement model there are not relations between indicators (manifest/observed variables).

After determining the Cronbach's alpha coefficient for the structure describing the latent variable respondent's functioning in a household, it turned out that the reliability is very low (Table 3). For this reason, variables that reduced the quality of the model were removed. In all three generational groups, the same observable variables were removed. These were quality of life was better before EU accession (X10), attachment to the place of residence (X13), convincing acquaintances to my opinion (X19). The rest of the established structure of the model has not been reduced. 
Table 3. Description of the model

\begin{tabular}{|c|c|c|c|c|}
\hline \multirow{2}{*}{ Construct } & \multirow{2}{*}{ Manifest variables } & \multicolumn{3}{|c|}{$\begin{array}{l}\text { Assessment of Constructs } \\
\text { Reliability Coefficient }\end{array}$} \\
\hline & & Y & $\mathrm{X}$ & BB \\
\hline Household - HH & $\begin{array}{l}\text { X4 - personal situation at work, } \\
\text { X5 - financial condition of the household, } \\
\text { X8 - satisfaction with one's life, } \\
\text { X9 - expectations from one's life, } \\
\text { X10 - quality of life was better before EU } \\
\text { accession, } \\
\text { X13 - attachment to the place of residence, } \\
\text { X19 - convincing acquaintances to my } \\
\text { opinion }\end{array}$ & $\begin{array}{c}\mathrm{CR}=0.64^{* *} \\
\mathrm{AVE}=0.35^{* *} \\
\alpha=0.26^{*} \\
\alpha=0.73^{* *}\end{array}$ & $\begin{array}{c}\mathrm{CR}=0.73^{* *} \\
\mathrm{AVE}=0.44^{* *} \\
\alpha=0.31^{*} \\
\alpha=0.72^{* *}\end{array}$ & $\begin{array}{c}\mathrm{CR}=0.73^{* *} \\
\mathrm{AVE}=0.43^{* *} \\
\alpha=0.28^{*} \\
\alpha=0.72^{* *}\end{array}$ \\
\hline Country - C & $\begin{array}{l}\text { X1 - general condition of the country, } \\
\text { X2 - evaluation of the country's economy, } \\
\text { X6 - evaluation of the country's jobs } \\
\text { market, } \\
\text { X7 - evaluation of public services, } \\
\text { X11 - satisfaction with democracy in the } \\
\text { country, } \\
\text { X14 - attachment to the country, } \\
\text { X18 - my voice counts in the country }\end{array}$ & $\begin{array}{c}\mathrm{CR}=0.81 \\
\mathrm{AVE}=0.4 \\
\alpha=0.8\end{array}$ & $\begin{array}{c}\mathrm{CR}=0.82 \\
\mathrm{AVE}=0.42 \\
\alpha=0.83\end{array}$ & $\begin{array}{c}\mathrm{CR}=0,82 \\
\mathrm{AVE}=0,42 \\
\alpha=0.82\end{array}$ \\
\hline $\begin{array}{l}\text { European Union } \\
- \text { EU }\end{array}$ & $\begin{array}{l}\mathrm{X} 3 \text { - evaluation of the EU economy, } \\
\mathrm{X} 12 \text { - satisfaction with EU democracy, } \\
\mathrm{X} 15 \text { - attachment to the EU, } \\
\mathrm{X} 16 \text { - attachment to Europe, } \\
\mathrm{X} 17 \text { - my voice counts in the EU }\end{array}$ & $\begin{array}{c}\mathrm{CR}=0.73 \\
\mathrm{AVE}=0.4 \\
\alpha=0.73\end{array}$ & $\begin{array}{c}\mathrm{CR}=0.75 \\
\mathrm{AVE}=0.37 \\
\alpha=0.75\end{array}$ & $\begin{array}{c}\mathrm{CR}=0,73 \\
\mathrm{AVE}=0,36 \\
\alpha=0.73\end{array}$ \\
\hline
\end{tabular}

"For all observed variables described as latent variable.

${ }^{* *}$ For $\mathrm{X} 4, \mathrm{X} 5, \mathrm{X} 8, \mathrm{X} 9$ as described latent variable.

Source: own elaboration on Standard Eurobarometer Data using IBM Imago.

After estimating the model, the Construct Reability and Average Variance Extracted coefficients were calculated. Their values are presented in Table 3. For almost all constructs in the three analysed models the AVE was close to 0.50 , and the CR was higher than the 0.7 excepted description of the latent variable $\mathrm{HH}$ in the model for Generation Y. The latent factor of functioning of individuals in a household $(\mathrm{HH})$ showed the worst convergent validity in the model for Generation $\mathrm{Y}(\mathrm{AVE}=0.35$ and $\mathrm{CR}=0.64)$, even if the measurement reliability indicates a good set of observable variables (Cronbach's alpha $>0.7$ ). The best Cronbach's alpha, AVE and CR values were obtained in all models for the latent factor of functioning of individuals in a country (C).

Table 4 shows the values of goodness-of-fit coefficients for the estimated models with the use of SLS for the three generations. Not all indicators presented in Table 2, are counted in SLS. 
Table 4. Indicators for the evaluation of the goodness-of-fit for the estimated models

\begin{tabular}{|l|c|c|c|}
\hline \multicolumn{1}{|c|}{ Indicator } & Generation Y & Generation X & Generation BB \\
\hline RMR & 0.123 & 0.116 & 0.115 \\
(RMR for independent model) & $(0.399)$ & $(0.454)$ & $(0.449)$ \\
\hline GFI & 0.953 & 0.965 & 0.967 \\
\hline NFI & 0.917 & 0.942 & 0.944 \\
\hline CMIN & $4601.5, p=0.0$ & $4501.5, p=0.00$ & $5688.23, p=0.0$ \\
\hline
\end{tabular}

Source: own elaboration using the Amos program on Standard Eurobarometer Data.

The majority of indicators evaluating the quality of the model (Table 4) assumed the values sufficient for its acceptance.

Figures 1 to 3 present in graphic form the estimated models with the assessed standardized values of the parameters.

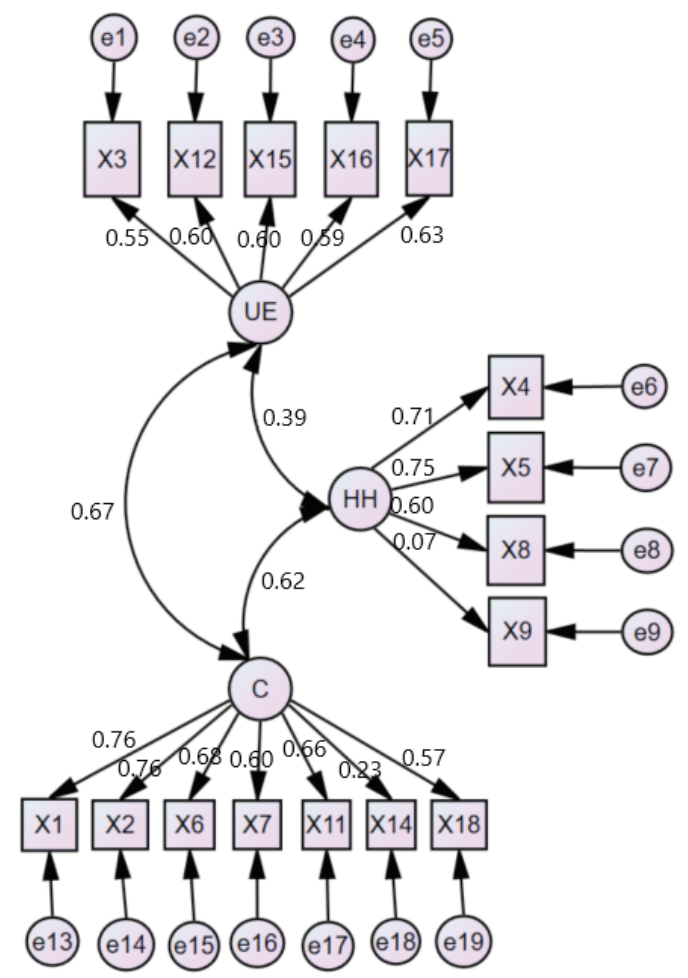

Figure 1. Estimated model for Generation Y

Source: own elaboration using the Amos program on Standard Eurobarometer Data. 


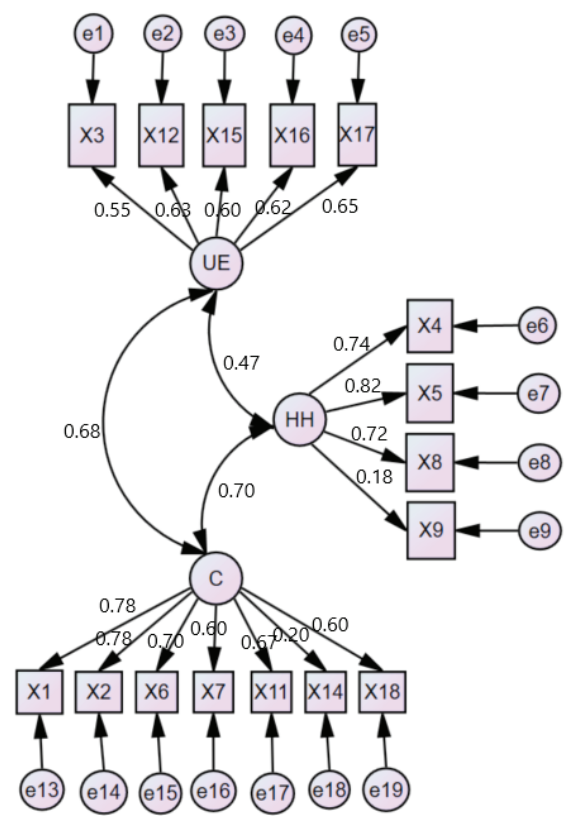

Figure 2. Estimated model for Generation X

Source: own elaboration using the Amos program on Standard Eurobarometer Data.

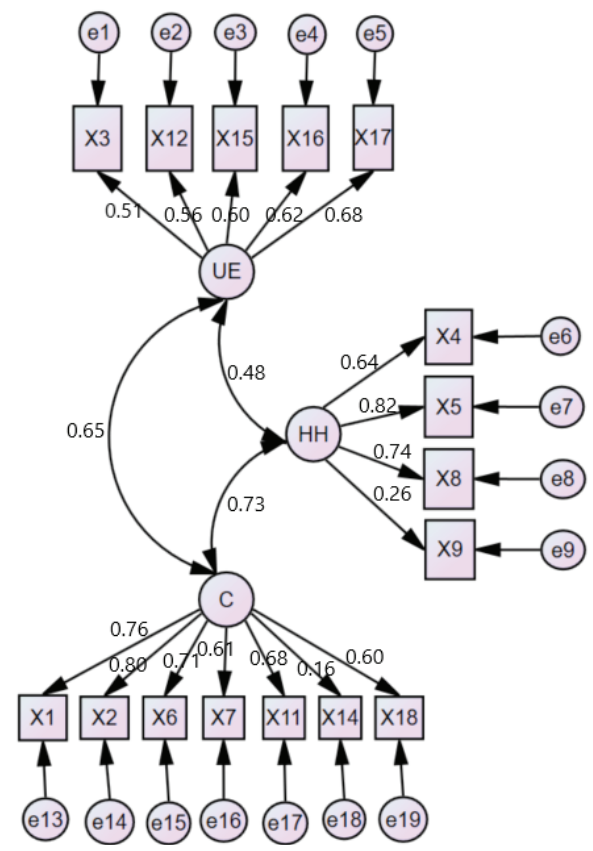

Figure 3. Estimated model for Generation BB

Source: own elaboration using the Amos program on Standard Eurobarometer Data. 


\section{Results of the analysis}

In all of the three groups of generations there occur significant correlations between the latent factors in pairs functioning of individuals in the country and EU as well as in the country and a household. It can be indicated that the opinion about the condition of the household is formed based on the opinion about the situation in the country (and vice-versa). The correlation coefficient for this pair is in the models for Y-ers, and X-ers the highest. The lowest relations occur between the opinion about the household and the opinion about the situation in the EU (in all models).

For generation BB (Figure 3), the factor which has the strongest impact on the opinion about the condition of the household was the evaluation of financial standing, followed by satisfaction with life and with professional standing. Whereas for generations $\mathrm{X}$ and $\mathrm{Y}$ the most important aspect first was the financial condition of the household and then (in a different order than for the BB generation) were professional standing and then satisfaction with life. The observed variable X9 (expectations about life) was not really important for the youngest generations, but also for generations $\mathrm{X}$ and $\mathrm{BB}$ the standardized regression weights were the lowest.

In the case of the opinion about the functioning of individuals in the country of residence, the opinions about the country's economy and the general condition of the country are most important for all of the analysed generations. Next, evaluations of a country's job market and satisfaction with democracy in the country were important for the level of satisfaction with functioning in the country in models for X-ers and BBs. For the latent variable related to the individual's functioning in the EU and in Europe the feelings about the statement my voice counts in the EU were important for all generations. For the youngest respondents important was also satisfaction with EU democracy, and for Xers European democracy and the opinions about feeling one's attachment to Europe (X16). The observed variable X16 has a great influence on the perception of individual's functioning in the EU and in Europe for generation BB.

\section{Conclusions}

The conducted analysis and conclusions made it possible to meet the main objectives and application purpose assumed in the study. The study performed using SEM enabled the identification of significant manifest variables indicative of life satisfaction in all constructs describing the three areas of functioning of the individuals. In addition, the use of a uniform confirmatory model for three age cohorts of Europeans gave the opportunity to compare the 
generations' perception of life satisfaction in relation to the relationship with three areas of individuals' functioning and to identify differences in the importance of manifest factors. Thus, the application goal was also achieved.

The use of SEM with a confirmatory factor analysis is well-based for the presented research problem. The use of a wide set of methods to assess the quality and fit of the estimated model indicates the path to be chosen in the analysis.

For the analysed structure of latent factors, chosen indicators of Constructs' Assessment and Reliability did not always indicate the good quality of the model. This conclusion was confirmed after analysing standardized regression coefficients. In all of the models, the construct respondents' functioning in household $(\mathrm{HH})$ was described by the variable $\mathrm{X} 9$ (expectations about life), which showed little effect on the change in its value. It should also be noted that the assumption of the existence of strong relationships of impact between constructs: household, country and EU/Europe, has not been confirmed, because in the created model the correlation coefficients between the $\mathrm{HH}$ and EU constructs are lower than 0.5. So the first hypothesis (H1) has not been fully confirmed. As a result of creating the model, it was possible to indicate sets of observable variables that significantly affected hidden variables (the hypothesis $\mathrm{H} 2$ was confirmed). Furthermore, the model structures did not differ significantly between the generations (the hypothesis H3 was not confirmed).

However, the study has significant cognitive values. The conclusions drawn from the conducted analysis direct further research on this topic. Further analyses will be carried out after the elimination of observable variables with the lowest impact on the constructs and change of assumptions about the relationship between latent factors. Analyses by social groups will also be carried out. However, in this case it will be necessary to check whether the assumption about the multidimensional normal distribution will be met, because with a reduced sample size it will be necessary to change the model estimation method.

\section{References}

Backhaus, K., Erichson, B., Plinke, W., Weiber R. (2003). Multivariate Analysemethoden. Berlin: Springer.

Bąkowska, J. (2013). Managing Generation Y Employees in an International Company. Working Papaers in Management, Finance and Economics, No. 1 [14] 2013. 
Belleau, B.D., Summers, T.A., Xu, Y., Pinel, R. (2007). Theory of reasoned action: purchase intention of young consumers. Clothing and Textiles Research Journal, 25 (3), 244-257. DOI: $10.1177 / 0887302 X 07302768$.

Biesok, G., Wyród-Wróbel, J. (2016). Modele satysfakcji klienta. Warszawa: Difin.

Byrne, B.M. (2001). Structural Equation Modelling with AMOS. Basic Concepts, Applications, and Programming. New York-London: Routledge Taylor \& Francis Group.

European Commission (2019). Eurobarometer 90.3(2018). Kantar Public [producer]. GESIS Data Archive, Cologne. ZA7489 Data file Version 1.0.0. DOI: 10.4232/1.13254.

Favero, W.L., Heath., G.R. (2012). Generational perspectives in the workplace: interpreting the discourses that constitute women's struggle to balance work and life. Journal of Business Communication, 49 (4), 332-356. DOI: 10.1177/0021943612456037.

Greenacre, M. (2010). Biplots in Practice. Bilbao: Fundacion BBVA.

Hansen, J.-I.C., Leuty, M.E. (2012). Work values across generations. Journal of Career Assessment, 20 (1), 34-52. DOI: 10.1177/1069072711417163.

Haque, M.M., Maheshwari, N. (2015). Consumer ethnocentrism and influence of role model on generational cohorts' purchase intentions towards herbal products. Asia-Pacific Journal of Management, Research and Innovation, 11 (4), 305-312. DOI: $10.1177 / 2319510 X 15609989$.

Januszewski, A. (2011). Modele równań strukturalnych w metodologii badań psychologicznych. Problematyka przyczynowości w modelach strukturalnych i dopuszczalność modeli. Studia z Psychologii w KUL, 17, 213-245.

Kim J.-O., Mueller, C. (1978). Factor Analysis. Statistical Methods and Practical Issues. Beverly Hills: Sage Publication Inc.

Konarski, R. (2009). Modele równań strukturalnych. Teoria i praktyka. Warszawa: Wydawnictwo Naukowe PWN.

Lichy, J. (2012). Towards an international culture: Gen Y students and SNS? Active Learning in Higher Education, 13 (2), 101-116. DOI: 10.1177/1469787412441289.

Long, J.S. (1983). Confirmatory Factor Analysis. A preface to LISREL. Beverly Hills: Sage Publication Inc.

Lyons, S.T., Duxbury, L., Higgins, C. (2007). An empirical assessment of generational differences in basic human values. Psychological Reports, 101 (2), 339-352. DOI: 10.2466/ pr0.101.2.339-352.

Madudova, E., Fabuš, J. (2017). A study of consumer behaviour of active usage of instant messaging applications. International Journal of Economics, Business and Management Research, 1 (5), 350-357. 
Mencl, J., Lester, S.W. (2014). More alike than different: what generations value and how the values affect employee workplace perceptions. Journal of Leadership \& Organizational Studies, 21 (3), 257-272. DOI: 10.1177/1548051814529825.

Ngobo, P.-V., Devallet-Ezanno, D. (2010). Do generations matter in customer defection? Recherche et Applications En Marketing (English Edition), 25 (3), 85-112. DOI: 10.1177/205157071002500304.

Osińńska, M., Pietrzak, M.B., Żurek, M. (2011). Wykorzystanie modeli równań strukturalnych do opisu psychologicznych mechanizmów podejmowania decyzji na rynku kapitałowym. Acta Universitatis Nicolai Copernici. Ekonomia XLII - Nauki humanistyczno-społeczne, 402, 9-21.

Panek, T. (2014). Poziom i jakość życia. In: T. Panek (ed.), Statystyka społeczna (pp. 117-161). Warszawa: Polskie Wydawnictwo Ekonomiczne.

Parry, E., Urwin, P. (2011). Generational differences in work values: a review of theory and evidence. International Journal of Management Reviews, 13, 79-96. DOI: 10.1111/j.14682370.2010.00285.x.

Ptak-Chmielewska, A. (2009). Metoda głównych składowych i analiza czynnikowa. In: E. Frątczak (ed.), Wielowymiarowa analiza statystyczna. Teoria - przykłady zastosowań z systemem SAS. Warszawa: Szkoła Główna Handlowa w Warszawie.

Sagan, A. (2003). Zmienne jakościowe w modelowaniu strukturalnym. In: E. Gatnar (ed.), Analiza i prognozowanie zjawisk rynkowych o charakterze niemetrycznym. Katowice: Prace Naukowe Akademii Ekonomicznej w Katowicach.

Sagan, A. (2018). Analiza ścieżkowa w badaniach marketingowych. Kraków: Wydawnictwo Uniwersytetu Ekonomicznego w Krakowie.

Sęk, H. (1993). Jakość życia a zdrowie. Ruch Prawniczy, Ekonomiczny i Socjologiczny, 2, 110117.

Słaby, T. (1990). Poziom życia, jakość życia. Wiadomości statystyczne, 6, 8-10.

Soulez, S., Guillot-Soulez, C. (2011). Recruitment marketing and generational segmentation: a critical analysis based on a sub-segment of Generation Y. Recherche et Applications en Marketing, 26 (1), 39-55.

Stanimir, A. (2020). Methods of a multivariate analysis of non-metric data in evaluating the generational perception of social characteristics. Folia Oeconomica Stetinensia, 20 (1), 390-407. DOI: 10.2478/foli-2020-0023.

Sztemberg-Lewandowska, M. (2008). Analiza czynnikowa w badaniach marketingowych. Wrocław: Wydawnictwo Uniwersytetu Ekonomicznego we Wrocławiu.

Szymańska, A. (2016). Założenia formalne modeli weryfikowanych za pomocą układów równań strukruralnych. Studia Psychologica UKSW, 16 (2), 93-116. 
Treuren, G., Anderson, K. (2010). The employment expectations of different age cohorts: is Generation Y really that different? Australian Journal of Career Development, 19 (2), 49-61. DOI: 10.1177/103841621001900207.

Twenge, J.M., Campbell, S.M., Hoffman, B.J., Lance, C.E. (2010). Generational differences in work values: leisure and extrinsic values increasing, social and intrinsic values decreasing. Journal of Management, 36 (5), 1117-1142. DIU: 10.1177/0149206309352246.

Twenge, J.M., King, L.A. (2005). A good life is a personal life: Relationship fulfilment and work fulfilment in judgments of life quality. Journal of Research in Personality, 39 (3), 336-353. DOI: 10.1016/j.jrp.2004.01.004.

Vui-Yee1 K., Khoo, P. (2018). The effect of work fulfilment on job characteristics and employee retention: Gen Y employees. Global Business Review, 21 (2), 1-15. DOI: 10.1177/0972150918778912. 